\title{
An Examination of Understandings of Prospective Teachers About Science and Science History*
}

\author{
Cemalettin Yildiz \\ Correspondence: Cemalettin Yildiz, Giresun University, Faculty of Education, Department of Mathematics and Science \\ Education, Giresun, Turkey.
}

Received: February 13, 2018

Accepted: April 17, $2018 \quad$ Online Published: April 21, 2018

doi:10.11114/jets.v6i6.3012

URL: https://doi.org/10.11114/jets.v6i6.3012

\begin{abstract}
The purpose of this study was to reveal beliefs of prospective teachers about "science" and "science history". The qualitative research approach was employed in the study. The study group consisted of 150 prospective teachers. A form developed by the researcher was used for data collection. The form consisted of open-ended questions. The data was analyzed using the content analysis method. As a result of the study, it was found that the prospective teachers explained science and science history mostly with the procedural understanding dimension. It was also found that the prospective teachers attributed the low number of female scientists mostly to socio-cultural factors, and success in science to cognitive factors. Lastly, the prospective teachers had positive beliefs about the contribution of science history to cognitive and affective domains, and believed that enriching courses with science history could be done by adopting a teacher-centered approach which involves the teacher's explaining lives, works, or inventions of various scientists. It is recommended that conceptual, procedural, and contextual dimensions of science are addressed in courses related to science history, and prospective teachers should be informed about how to use science history in their classes.
\end{abstract}

Keywords: pre-service teachers, science, history of science, teacher training

\section{Introduction}

Since the beginning of history, humans have wanted and tried to dominate the nature. Hence, it has become a significant need for humans to understand and explain the universe and the environment (Yildirim, 2003). This need is met by science, which is a mental process. Derived from the Latin word "scientica", referred to as "wissenschaft" in German and "ilim" or "fen" in Ottoman Turkish, science can be defined as "obtaining knowledge, research for the purpose of learning" (Dogan, 2016, p.3). Science can be defined as "accumulation of knowledge striving to establish laws related to a certain part of the universe or certain events by utilizing empirical methods and tools" (Turkish Language Association Dictionary [TLAD], 2011, p.339). Science is a common product of the humanity, and the process has begun with the emergence of the humankind. While changing life conditions of people with technology on one hand, science also gives a rational quality to our thinking on the other (Yildirim, 2003). There have been significant changes in outlook to science throughout its historical process, and the traditional view of science has been replaced by the contemporary view of science (Bilen, 2015). Based on the study conducted by Palmquist and Finley (1997), characteristics of traditional and contemporary views of science may be explained as follows:

In the traditional view, science consists only of knowledge. In this view, the purpose of science is to reach true knowledge through experiment. In the contemporary view, science is an experience, a process, a venture relying on competition, and an organization of information to better understand the nature. Also, science consists of numerous disciplines and methods in this view.

Since to know the past has a significant role in understanding today and tomorrow, humans frequently refer to history (Topdemir \& Unat, 2008). In this context, science can only be understood by examining it with its historical development process (Yildirim, 2007). The historical development process of science is addressed by history, which has been gaining popularity in recent years. Science history was introduced to fill the gap between science and history (Fazlioglu, 2004). Science history aims to illuminate the development process of all branches of science; however, it

\footnotetext{
*This study is an expanded version of that verbally presented in "International Conference on Research in Education and Science" (2015, Antalya, TURKEY).
} 
focuses on separate histories of all branches (Tekeli et al., 2007). In this sense, science history can be defined as birth and development stories of branches of science (Ortas, 2005a). It is also possible to define science history as a discipline which addresses how science came to existence, contributions made to science, specific dates of such contributions, and efforts made and methods used by scientists to contribute to science (Tekeli et al., 1997).

Science history does not only mention what people of old did; it also serves as a step for new scientific and technological developments by opening new horizons (Bayrakdar, 2009). Studying science history allows students to see science as an occupation which they can understand and contribute to (Appelget, Matthews, Hildreth, \& Daniel, 2002). This may help raise contemporary scientists who can use their imagination and creativity, act with curiosity, and inquire about various topics. Science history is also useful in that it helps students think about the importance of science and understand it with its various aspects (Topdemir \& Unat, 2008).

Teachers may use science history improve students' conceptual, procedural, and contextual understandings regarding science (Wang \& Marsh, 2002). The conceptual dimension of science pertains to how scientific ideas are described and their role in science history (Lacin Simsek, 2011). In order to improve conceptual understanding related to science, it is necessary to emphasize that scientific knowledge could change with new discoveries and enrich it with a historical perspective (Lacin Simsek, 2009). The procedural dimension of science involves processes such as thinking, experimenting, questioning, researching, decision-making, inferring, extrapolating, elaborating, reporting, and implementing (Wang \& Marsh, 2002). As a process, science can be considered as a pattern of operational and mental procedures (Yildirim, 2007). The contextual dimension of science involves "how scientific research improves people's life quality" (Kocyigit \& Pektas, 2017), and "characteristics and working conditions of scientists, and the relationship between development of scientific knowledge and economic, psychological, social, cultural, and political conditions of scientists" (Lacin Simsek, 2011). In summary, students may better understand conceptual, procedural, and contextual dimensions of science by studying science history. Also, learning these three different dimensions of science may allow students to develop an accurate and contemporary understanding about science.

Although science history is one of the significant concepts of recent years (Justi \& Gilbert, 1999; Rutherford, 2001; McComas, 2008), it has been a neglected subject in Turkey, from primary school to university level (Ortas, 2005b). Science history has been added to the curriculum in undergraduate programs with the reconstruction of undergraduate programs in the faculty of education in 2006 (Council of Higher Education [CoHE], 2007). This has resulted in the addition of the "Nature of Science and Science History" course in the science teaching program, and the "Science History" course in mathematics teaching, guidance and psychological consulting, and computer and educational technologies teaching programs. In these courses, prospective teachers learn about contributions of different civilizations and scientists to science and science history throughout the historical process of science (Bozdogan, Sengul, \& Bozdogan, 2013). Learning about working conditions of scientists, the development of science and factors affecting it brings along an accurate understanding of science and science history (Monk \& Osborne, 1997). Considering these benefits, addition of courses related to science history into undergraduate programs may be seen as a big step. Using science history in courses is quite important in that it helps students understand science and science history (Abd-El-Khalick, 2005; Posnanski, 2010; Yenice, 2015). However, it is necessary to find our awareness levels of prospective teachers regarding science and science history in order to make effective use of science history in courses.

\subsection{Literature Review}

Some studies in the literature on opinions of teachers and prospective teachers about science and science history are briefly summarized below:

Akerson, Abd-El-Khalick, and Lederman (2000) found that prospective teachers and teachers had limited information about subjective aspects of science and its relationship with society and culture in particular. Celik (2003) revealed that prospective teachers defined science mostly with dimensions of process and information structure, and their understanding about the nature of scientific knowledge was compatible with contemporary scientific approaches. Kenar (2008) revealed that senior prospective science teachers had contemporary views about the creative and imaginative nature of science. Aslan, Yalcin, and Tasar (2009) found that science teachers had sufficient knowledge about effects of social and cultural factors on scientists and scientific studies; however, they had limited knowledge and misconceptions about the definition of science.

In a study conducted by Lacin Simsek (2011), it was found that science and technology teachers had an inadequate understanding about the importance of science history, and mostly used science history to contribute to improvement of their students in the cognitive domain. Also, it was observed that teachers taught science history by telling life stories of scientists, mentioning historical development processes of scientific subjects, giving research or project assignments, presenting examples from science history for certain subjects, and telling stories from science history. Ayvaci and Senel Coruhlu (2012) found that about one fourth of prospective science and technology teachers defined science as 
"accumulation of knowledge striving to establish laws related to a certain part of the universe or certain events by utilizing empirical methods and tools".

Hacieminoglu, Ertepinar, and Yilmaz-Tuzun (2012) revealed that prospective science teachers had positive perceptions about the use of science history in courses; however, had insufficient knowledge about science history. Also, a high correlation was found between perceptions and applications of prospective teachers related to science history. Finally, after starting their careers as teachers, the most frequently addressed dimension by prospective teachers in their applications related to science history was found to be the conceptual dimension, whereas the contextual dimension was mentioned the least. Sarac (2012) revealed that prospective and in-service classroom teachers had contemporary opinions related to the effect of science on the society, the effect of the society on science, and the nature of scientific knowledge.

Atalay (2013) found that science and technology teachers had limited knowledge about the empirical and indeterminate nature of science, observation and inference in science, and social and cultural influences in science, while they had sufficient knowledge about the significance of creativity and imagination in science. Cinar and Koksal (2013) found that prospective social studies teachers had contemporary opinions about scientific observation, the changeability of scientific knowledge, and cause-effect relationships in science, whereas they had traditional opinions about the definition of science, scientific methods, and basic assumptions of science. Yenice, Ozden, and Balci (2015) determined that prospective science and classroom teachers had contemporary ideas about the society-science and science-society interaction, characteristics of a scientist, the provisionality and changeability of scientific knowledge. Cetiner (2016) revealed that physics activities involving initial experiments in science history maintained prospective teachers' interest in the course, helped them understand basic concepts in physics, and ensured positive attitudes toward the activity.

No study was found investigating understandings of prospective teachers on both science and science history. For this reason, it is believed that there is a need for detailed studies on concepts of science and science history, opinions of prospective teachers about these concepts. We believe that this study, which was conducted with the idea that it would fill a significant gap in the literature related to determining understandings of prospective teachers regarding science and science history, will be useful for prospective teachers, teachers, and academics who want to acquire knowledge about science and science history, and contribute to the literature in this sense.

\subsection{The Aim of the Study}

An examination of reformation efforts in Turkish, Australian, Chinese, Canadian, New Zealand, South American, British, and American educational systems would reveal that science and science history were added as basic concepts in curricula of these countries (Yenice, 2015). The addition of science and science history to curricula may be seen as an important step. Considering that those who will implement these curricula are raised in the faculty of education, it is important to determine beliefs of prospective teachers enrolled in various programs regarding science and science history. Therefore, the purpose of this study is to reveal beliefs of prospective teachers about science and science history.

\section{Method}

This is a qualitative study conducted to determine beliefs of prospective teachers about science and science history. Qualitative research is a method used to examine beliefs emerging from experiences of participants in a systematic manner (Ekiz, 2009). The qualitative research approach was employed in the present study to examine beliefs of participants emerging from their personal experiences in a systematic manner (Strauss \& Corbin, 1998).

\subsection{Study Group}

The maximum diversity sampling was used in the study to collect more comprehensive data for the solution of the research problem and reflect the diversity among individuals at the highest level possible (McMillan \& Schumacher, 2006). The study group consisted of senior prospective teachers. Table 1 gives information related to undergraduate programs and genders of prospective teachers:

Table 1. Some demographic characteristics of the prospective teachers

\begin{tabular}{lccc}
\hline \multicolumn{1}{c}{ Programs } & Female & Male & Total \\
\hline Elementary School Mathematics Teaching & 40 & 9 & 49 \\
Science Teaching & 31 & 8 & 39 \\
Guidance and Psychological Counseling & 26 & 10 & 36 \\
Computer and Educational Technologies Teaching & 22 & 4 & 26 \\
\hline \multicolumn{1}{c}{ Total } & 119 & 31 & 150
\end{tabular}

As shown Table 1, 150 prospective teachers participated in the study. 119 participants were female and 31 were male. 


\subsection{Implementation Process}

First of all, the prospective teachers were informed about the study explaining that it was a research on male and female scientists who had contributed to science and history. In order to include as many scientists as possible, each prospective teacher was assigned a different scientist. The prospective teachers made presentations of about 20 minutes on scientists in the "Science History" course or the "Nature of Science and Science History" course. Science history was examined under eight periods (Yorukogullari \& Ihsanoglu, 2013), and scientists were selected from each period shown in Table 2.

Table 2. The periods examined within the scope of the study and the number of scientists selected for each period

\begin{tabular}{lc}
\hline \multicolumn{1}{c}{ Periods } & $\mathrm{f}$ \\
\hline 1.Science and Technology in Ancient Greece and The Hellenistic Period & 22 \\
2.Science and Technology in The Roman Period & 11 \\
3.Science and Technology in Middle Ages & 25 \\
4.Science and Technology in The Initial Islamic Period of Turks & 8 \\
5.Science and Technology in Renaissance and The Enlightenment Period & 22 \\
6.Science and Technology in The Ottoman Period & 19 \\
7.Science and Technology in The New Age & 20 \\
8.Science and Technology in The Republican Period & 23 \\
\hline
\end{tabular}

As shown in Table 2 , the prospective teachers were assigned a total of 150 scientists to research.

The prospective teachers were asked to research a given scientist. Some criteria were developed to help the prospective teachers prepare their presentations, and better understand conceptual, procedural, and contextual dimensions of science and science history. These criteria included "the period when the scientist lived and life conditions in this period", "the life, works, inventions, and quotes of the scientist", "significant events, anecdotes, or stories from the scientist's life", "reasons driving the scientist to work and research, and challenges faced by the scientist in the process" (Yildiz \& Gokcek, 2013).

In the first three weeks of the "Science History" course and the "Nature of Science and Science History" course, the prospective teachers were given information about characteristics of science, science history, the purpose of science history, learning and teaching science history, and contributions of different civilizations from different geographic regions to science (Science in Central Asia, China, India, Mesopotamia, Ancient Egypt, Anatolia, Aegean Basin, Ionia, and Ancient Greece). Then, the prospective teachers made their presentations about their given scientist. During the presentations, the researcher touched upon important points, and held discussions with the prospective teachers using the question-answer method. After all the presentations were completed, pictures of scientists were printed on rugs, and puzzles related to various scientists were prepared to help students familiarize with scientists. These materials were presented in the "Science History Exhibition" for two days. The prospective teachers in the Elementary School Mathematics Teaching program (between 09:00-12:00) and the Science Teaching program (between 13:00-16:00) provided visitors with information about scientists for the first day, and the prospective teachers in the Guidance and Psychological Counseling program (between 09:00-12:00) and the Computer and Educational Technologies Teaching program (between 13:00-16:00) took the shift for the second day.

\subsection{Data Collection Tool}

It is noted in the literature that there is an increasing need for researching beliefs of individuals related to science history in detail (Metin, 2009). For this reason, the researchers developed a qualitative data collection tool consisting of open-ended questions to collect in-depth information about beliefs of individuals related to science history (Lederman, Abd-El-Khalick, Bell, \& Schwartz, 2002). A form consisting of six open-ended questions was used for data collection. The form had two sections. The first section contained questions about genders and undergraduate programs of the prospective teachers. The second section included six open-ended questions about science and science history. Blank spaces were left under each question for answers. A literature review was performed to create the questions, and contents of the "Science History" course and the "Nature of Science and Science History" course were examined. Thus, the questions on the definition of science and science history, factors enabling success in science, reasons behind the low number of female scientists, benefits of learning science history, how to use science history in courses were created, and a pilot study was conducted with 15 prospective teachers using the draft form. The questions in the form were reviewed after the pilot study, and the results were presented to three experts. The questions in the form were finalized in accordance with expert opinions. The questions used in the study were as follows: 
"How would you define science?", "How would you define science history?", "What are the factors enabling success in science? Why?", "What is the reason behind the low number of female scientists in science history?", "What are the benefits of using science history in courses?", and "How could we enrich courses using science history?"

\subsection{Collection of Data}

The form was applied to the prospective teachers at the end of the study. The research and presentation process of the prospective teachers took 11 weeks to complete. The form was applied one week after the science history exhibition. Thus, the information retained in minds of the prospective teachers was determined.

\subsection{Data Analysis}

The data was analyzed using the content analysis method. In content analysis, the data is firstly conceptualized, and then logically organized and categorized based on resulting concepts (Yildirim \& Simsek, 2011). Firstly, the researcher examined answers given by the prospective teachers and divided them into meaningful parts. These were then named and coded by the researcher. Then, the resulting codes were brought together, and common aspects among the codes were determined. Based on these common aspects, the categories were created to gather the codes under certain concepts. Then, the data was organized according to the codes and the categories. The results of the analysis were presented in tables with frequency and percentage values. Since some prospective teachers used more than one code in their answers, the sum of code frequencies may be higher than the total number of prospective teachers. In order to improve the validity and internal consistency of the findings, sample sentences related to opinions of the prospective teachers about science and science history were given below the tables without any changes. As required by research ethics, the prospective teachers were named as "P1, P2, P3, .., P150".

The forms filled by the prospective teachers were encoded by the researcher for reliability calculations, and the resulting codes were placed under certain categories. The resulting codes and categories were submitted to an expert with substantial experience in qualitative data analysis. Then, the researcher and the expert reviewed the agreement level in the forms filled by the prospective teachers. The researcher and the expert discussed the codes causing conflict and agreement, and necessary adjustments were made. The reliability coefficient was calculated to be $89 \%$ using the following formula (Miles \& Huberman, 1994): [Agreement / (Agreement + Disagreement) x 100]. Studies with a reliability value above $70 \%$ indicate are accepted to be reliable (Miles \& Huberman, 1994).

\section{Results}

The categories and codes derived from answers given by the prospective teachers were presented in tables.

The codes derived from answers of the prospective teachers related to the definition of science can be seen in Table 3 together with frequency and percentage values:

Table 3. The definition of science according to the prospective teachers

\begin{tabular}{|c|c|c|c|}
\hline Categories & Codes & $\mathrm{f}$ & $\%$ \\
\hline \multirow{7}{*}{$\begin{array}{c}\text { Procedural } \\
\text { Understanding }\end{array}$} & 1.The endeavor or process of understanding the nature & 30 & 20.0 \\
\hline & 2.The endeavor or process of understanding the universe & 21 & 14.0 \\
\hline & 3.People's discovering or finding new information & 15 & 10.0 \\
\hline & $\begin{array}{l}\text { 4.The process of establishing laws related to a certain part of the } \\
\text { universe or certain events by utilizing empirical methods and tools }\end{array}$ & 10 & 6.7 \\
\hline & $\begin{array}{l}\text { 5.The endeavor of understanding and explaining the nature, the man, } \\
\text { and the universe }\end{array}$ & 4 & 2.7 \\
\hline & $\begin{array}{l}\text { 6.Generation of empirical, theoretical, and applicable information } \\
\text { related to world by scientists }\end{array}$ & 1 & 0.7 \\
\hline & 7.A process which generates milestones in the history of humankind & 1 & 0.7 \\
\hline
\end{tabular}


Table 3. Continued

\begin{tabular}{clcc}
\hline Categories & \multicolumn{1}{c}{ Codes } & $\mathrm{f}$ & $\%$ \\
\hline \multirow{2}{*}{ Conceptual } & 8.The set of systematic knowledge & 38 & 25.3 \\
Understanding & 9.The body of information proven by experiments & 3 & 2.0 \\
& 10.The source of man's horizon & 1 & 0.7 \\
\hline \multirow{2}{*}{ Contextual } & 11.All information or works which facilitate human life & 20 & 13.3 \\
Understanding & 12.Useful information presented by research & 2 & 1.3 \\
& 13.The body of social and cultural developments & 1 & 0.7 \\
\hline
\end{tabular}

As shown in Table 3, the definitions of science made by the prospective teachers gathered under three different categories; "procedural understanding", "conceptual understanding", and "contextual understanding". Also, 20.0\% of the prospective teachers defined science procedurally as "the endeavor or process of understanding the nature", $25.3 \%$ defined it conceptually as "the set of systematic knowledge", and $13.3 \%$ defined it contextually as "all information or works which facilitate human life". Some quotes from the prospective teachers corresponding to codes 1,8 , and 11 in Table 3 can be found below:

"Science is an intellectual endeavor which reveals reasons behind and connections between natural events, and institutionalizes this knowledge. (P11)"

"Science is the set of systematic knowledge which represents the cause-effect relationship between natural events. (P34)"

"Science is all information generated and works performed to facilitate human life. (P35)"

The codes derived from answers of the prospective teachers related to the definition of science history can be seen in Table 4 together with frequency and percentage values:

Table 4 . The definition of science history according to the prospective teachers

\begin{tabular}{|c|c|c|c|}
\hline Categories & Codes & f & $\%$ \\
\hline \multirow{11}{*}{$\begin{array}{c}\text { Procedural } \\
\text { Understanding }\end{array}$} & 1.An examination of science's historical development & 71 & 47.3 \\
\hline & $\begin{array}{l}\text { 2.Examination of practices aimed at meeting needs of the humankind } \\
\text { throughout its existence }\end{array}$ & 19 & 12.7 \\
\hline & 3.Examination of lives, works, inventions, and mental frames of scientists & 18 & 12.0 \\
\hline & 4.Examination of generation, development, and use conditions of information & 17 & 11.3 \\
\hline & 5.Examination of all scientific work throughout the history & 15 & 10.0 \\
\hline & $\begin{array}{l}\text { 6.Process which explains how science and technology are used by the } \\
\text { humankind and what changes the use of science and technology cause in lives } \\
\text { of people }\end{array}$ & 6 & 4.0 \\
\hline & 7.A process which illuminates what people had done in the past & 6 & 4.0 \\
\hline & 8.Examination of studies on accumulation of information & 6 & 4.0 \\
\hline & $\begin{array}{l}\text { 9.Examination of changes, developments, and interactions in science } \\
\text { throughout the history }\end{array}$ & 3 & 2.0 \\
\hline & 10.Science's yesterday, today, and tomorrow & 3 & 2.0 \\
\hline & 11.Transfer of past knowledge to the next generation through scientific methods & 1 & 0.7 \\
\hline $\begin{array}{c}\text { Contextual } \\
\text { Understanding }\end{array}$ & $\begin{array}{l}\text { 12.Works performed by the humankind in order to understand their } \\
\text { environment, survive, and facilitate life }\end{array}$ & 5 & 3.3 \\
\hline
\end{tabular}

As shown in Table 4, the definitions of science made by the prospective teachers gathered under two different categories; "procedural understanding" and "contextual understanding". Also, $47.3 \%$ of the prospective teachers defined science history procedurally as "examination of science's historical development process", and 3.3\% defined it contextually as "works performed by the humankind in order to understand their environment, survive, and facilitate life". Some quotes from the prospective teachers corresponding to codes 1 and 12 in Table 4 can be found below: 
"Science history is the development process of science throughout the history. (P84)"

"Science history is the examination of science with its historical development process. (P88)"

"Science history addresses works performed by the humankind in order to understand their environment, survive, and facilitate life. (P12)"

The codes derived from answers of the prospective teachers related to cognitive factors necessary for success in science can be seen in Table 5 together with frequency and percentage values:

Table 5. Cognitive factors necessary to succeed in science according to the prospective teachers

\begin{tabular}{clcc}
\hline Category & \multicolumn{1}{c}{ Codes } & f & $\%$ \\
\hline \multirow{5}{*}{ 1.Hard work } & 35 & 23.3 \\
& 2.Being intelligent & 25 & 16.7 \\
& 3.Listening & 10 & 6.7 \\
& 4.Thinking & 8 & 5.3 \\
& 5.Researching & 7 & 4.7 \\
& 6.Improving one's self & 3 & 2.0 \\
Factors & 2 & 1.3 \\
& 7.Reading & 2 & 1.3 \\
& 8.Being knowledgeable & 2 & 1.3 \\
& 9.Observing & 2 & 0.7 \\
& 10.Producing solutions or ideas & 1 & 0.7 \\
& 11.Inventing & 1 & 0.7 \\
& 12.Critical thinking & 1 & 0.7 \\
& 13.Using one's mind & 1 & 0.7 \\
\hline
\end{tabular}

As shown in Table 5, 23.3\% of the prospective teachers mentioned "hard work", $16.7 \%$ mentioned "being intelligent", and $6.7 \%$ mentioned "listening" as a cognitive factor necessary for success in science. Some quotes from the prospective teachers corresponding to codes 1,2 , and 3 in Table 5 can be found below:

"What leads to success is being intelligent and hardworking, and keeping your mouth shut. Being male or female is not a criterion for success. (P2)"

"Gender has no role in scientific success... To be successful in science, one needs to be intelligent, hardworking... and keep one's mouth shut. (P3)"

"Albert Einstein said one needs to be intelligent, work hard, and keep one's mouth shut to be successful. These are what one needs to be successful in science. (P10)"

The codes derived from answers of the prospective teachers related to affective factors necessary for success in science can be seen in Table 6 together with frequency and percentage values:

Table 6. Affective factors necessary to succeed in science according to the prospective teachers

\begin{tabular}{clcc}
\hline Category & \multicolumn{1}{c}{ Codes } & f & $\%$ \\
\hline \multirow{4}{*}{ Affective } & 1.Being ambitious & 13 & 8.7 \\
& 2.Being brave & 9 & 6.0 \\
Factors & 3.Being patient & 8 & 5.3 \\
& 5.Being curious & 7 & 4.7 \\
& 6.Being eager & 6 & 4.0 \\
& 7.Having confidence & 4 & 2.7 \\
& 8.Being structured or disciplined & 4 & 2.7 \\
\hline
\end{tabular}


Table 6. Continued

\begin{tabular}{clcc}
\hline Category & \multicolumn{1}{c}{ Codes } & f & $\%$ \\
\hline \multirow{4}{*}{ Affective } & 9.Enjoying science & 3 & 2.0 \\
& 10.Enjoying hard work & 1 & 0.7 \\
Factors & 12.Being determined & 1 & 0.7 \\
& 13.Devoting one's self & 1 & 0.7 \\
& 14.Enjoying learning & 1 & 0.7 \\
& 15.Being lucky & 1 & 0.7 \\
\hline
\end{tabular}

As shown in Table $6,8.7 \%$ of the prospective teachers mentioned "being ambitious", $6.0 \%$ mentioned "being brave", and $5.3 \%$ mentioned "being patient" as an affective factor necessary for success in science. Some quotes from the prospective teachers corresponding to the first three codes in Table 6 can be found below:

“...Being ambitious and brave leads to success in science... (P15)”

“...Being successful in science requires courage, ambition, patience, and most importantly, intelligence... (P8)”

“...Being successful requires patience, hard work, and intelligence not only in science, but in any field. (P10)”

The codes derived from answers of the prospective teachers related to reasons behind the low number of female scientists can be seen in Table 7 together with frequency and percentage values:

Table 7. Reasons behind the low number of female scientists according to the prospective teachers

\begin{tabular}{|c|c|c|c|}
\hline Categories & Codes & $\mathrm{f}$ & $\%$ \\
\hline \multirow{18}{*}{$\begin{array}{c}\text { Socio-cultural } \\
\text { Factors }\end{array}$} & 1.Being denied a voice or an opportunity & 49 & 32.7 \\
\hline & 2.Social pressure & 41 & 27.3 \\
\hline & 3.Belief that women have low intelligence & 40 & 26.7 \\
\hline & 4.Lack of educational opportunities for women & 36 & 24.0 \\
\hline & 5.Belief that a woman's duty is to do housework or raise children & 34 & 22.7 \\
\hline & 6.Familial pressure & 31 & 19.3 \\
\hline & 7.Perception that science is for men & 28 & 18.7 \\
\hline & 8.Low or lack of value given to women & 27 & 18.0 \\
\hline & 9.Lack of attention paid to scientific studies conducted by women & 26 & 17.3 \\
\hline & 10.High number of responsibilities of women & 12 & 8.0 \\
\hline & 11.Lack of gender equality & 9 & 6.0 \\
\hline & 12.Patriarchal social structure & 7 & 4.7 \\
\hline & 13.Cultural pressure & 7 & 4.7 \\
\hline & 14.Use of "science man" instead of "science person" & 6 & 4.0 \\
\hline & 15.Difficult working conditions & 5 & 3.3 \\
\hline & 16.Lack of support for women & 3 & 2.0 \\
\hline & 17.Underage marriages & 1 & 0.7 \\
\hline & 18.Difficulty of maintaining the balance between career and family life & 1 & 0.7 \\
\hline \multirow{3}{*}{$\begin{array}{c}\text { Psychological } \\
\text { Factors }\end{array}$} & 19.Men's desire to play a dominant role & 5 & 3.3 \\
\hline & 20.Lack of confidence & 2 & 1.3 \\
\hline & 21.Women's low desire and interest in science & 1 & 0.7 \\
\hline $\begin{array}{c}\text { Economical } \\
\text { Factors }\end{array}$ & 22.Lack of opportunities & 3 & 2.0 \\
\hline
\end{tabular}

As shown in Table 7, the reasons behind the low number of female scientists mentioned by the prospective teachers 
gathered under three different categories; "socio-cultural factors", "psychological factors", and "economic factors". Also, the "Being denied a voice or an opportunity" code stood out in the socio-cultural factors category, whereas the "men's desire to play a dominant role" code stood out in the psychological factors category. The only code that stood out in the economic factors category was "lack of opportunities". Some quotes from the prospective teachers corresponding to codes 1, 19 and 22 in Table 7 can be found below:

“...Ruth Moufang completed her graduate studies in spite of great difficulties caused to her due to her gender, and was later denied a lectureship on account of her gender. She worked in private industry for ten years... (P16)"

“...Men's desire to play a dominant role prevented women from take steps in science. (P95)"

“...The number of female mathematicians is unfortunately low due to lack of opportunities. However, works of female mathematicians take an important place in history. (P15)”

The codes derived from answers of the prospective teachers related to benefits of using science history for the cognitive domain can be seen in Table 8 together with frequency and percentage values:

Table 8. Benefits of using science history for the cognitive domain according to the prospective teachers

\begin{tabular}{|c|c|c|c|}
\hline Category & Codes & $\mathrm{f}$ & $\%$ \\
\hline \multirow[b]{11}{*}{$\begin{array}{l}\text { Benefits } \\
\text { for The }\end{array}$} & 1.Learning about lives, works, inventions, or quotes of scientists & 26 & 17.3 \\
\hline & 2.Having more permanent knowledge & 24 & 16.0 \\
\hline & 3.Improving general knowledge & 22 & 14.7 \\
\hline & 4.Developing a perspective & 13 & 8.7 \\
\hline & 5.Having more meaningful knowledge & 12 & 8.0 \\
\hline & 6.Being more successful & 11 & 7.3 \\
\hline & 7.Better understanding the conditions of the time & 11 & 7.3 \\
\hline & 8.Learning about the structure of science & 8 & 5.3 \\
\hline & 9.Raising new scientists & 8 & 5.3 \\
\hline & $\begin{array}{l}\text { 10.Learning about historical development process of } \\
\text { mathematical symbols, concepts, or formulas }\end{array}$ & 8 & 5.3 \\
\hline & $\begin{array}{l}\text { 11.Acquiring accurate information about the historical } \\
\text { development of science }\end{array}$ & 7 & 4.7 \\
\hline Cognitive & 12.Establishing connections between past and future & 6 & 4.0 \\
\hline \multirow[t]{12}{*}{ Domain } & 13.Finding new information or methods & 5 & 3.3 \\
\hline & 14.Understanding how to associate science with everyday life & 5 & 3.3 \\
\hline & 15.Carrying out the class more efficiently & 4 & 2.7 \\
\hline & 16.Taking lessons from works of scientists & 3 & 2.0 \\
\hline & 17.Learning about the historical development of mathematics & 3 & 2.0 \\
\hline & 18.Preventing misconceptions & 3 & 2.0 \\
\hline & 19.Gaining awareness & 2 & 1.3 \\
\hline & 20.Understanding new information more easily & 2 & 1.3 \\
\hline & 21.Learning about old civilizations & 1 & 0.7 \\
\hline & 22.Mastering subjects & 1 & 0.7 \\
\hline & 23.Better understanding the importance of mathematics & 1 & 0.7 \\
\hline & 24. Revealing students' lack of knowledge & 1 & 0.7 \\
\hline
\end{tabular}

As shown in Table 8, 17.3\% of the prospective teachers mentioned "learning about lives, works, inventions, or quotes of scientists", $16.0 \%$ mentioned "having more permanent knowledge" and 14.7\% mentioned "improving general knowledge" as benefits of science history for the cognitive domain. Some quotes from the prospective teachers corresponding to codes 1,2 , and 3 in Table 8 can be found below:

"...The student learns about the information available to people in those periods, how they used the information, and 
challenges that they encountered... (P45)"

"...We learn about those who introduced and proved axioms, theories, and hypotheses that are available today, and challenges faced by scientists to engage in mathematics... (P52)"

"...The information learned by introducing a scientist is always more permanent. (P26)"

"It is quite useful to improve general knowledge... (P114)"

The codes derived from answers of the prospective teachers related to benefits of using science history for the affective domain can be seen in Table 9 together with frequency and percentage values:

Table 9. Benefits of using science history for the affective domain according to the prospective teachers

\begin{tabular}{|c|c|c|c|}
\hline Category & Codes & f & $\%$ \\
\hline \multirow{17}{*}{$\begin{array}{l}\text { Benefits } \\
\text { for The } \\
\text { Affective } \\
\text { Domain }\end{array}$} & 1.Holding up lives, works, inventions, or quotes of scientists as examples & 57 & 38.0 \\
\hline & 2.Attracting attention or interest & 23 & 15.3 \\
\hline & 3.Providing guidance & 15 & 10.0 \\
\hline & 4.Ensuring perseverance or determination & 14 & 9.3 \\
\hline & 5.Taking lessons from lives of scientists & 14 & 9.3 \\
\hline & 6.Arousing curiosity & 13 & 8.7 \\
\hline & 7.Encouraging hard work & 11 & 7.3 \\
\hline & 8.Motivating & 8 & 5.3 \\
\hline & 9.Encouraging to think & 4 & 2.7 \\
\hline & 10.Ensuring the student likes the course & 4 & 2.7 \\
\hline & 11.Encouraging to research & 4 & 2.7 \\
\hline & 12.Making the course more enjoyable & 5 & 3.3 \\
\hline & 13.Satisfying the sense of curiosity & 2 & 1.3 \\
\hline & 14.Improving confidence & 2 & 1.3 \\
\hline & 15.Making the teacher more valuable for the student & 1 & 0.7 \\
\hline & 16.Improving patriotism & 1 & 0.7 \\
\hline & 17.Providing mental relaxation for the student & 1 & 0.7 \\
\hline
\end{tabular}

As shown in Table 9,38.0\% of the prospective teachers mentioned "holding up lives, works, inventions, or quotes of scientists as examples", $15.3 \%$ mentioned "attracting attention or interest", and 10.0\% mentioned "providing guidance" as benefits of science history for the affective domain. Some quotes from the prospective teachers corresponding to the first three codes in Table 9 can be found below:

"The student can hold up works and efforts of male and female mathematicians as examples... (P41)"

“...When we provide information about a scientist when explaining a subject, it is easier to attract the student's attention. (P46)"

"Lives of scientists, the path that they followed, the way that they thin, and their other personality traits can provide us with guidance... (P93)"

The codes derived from answers of the prospective teachers related to how to enrich the course using science history can be seen in Table 10 together with frequency and percentage values:

Table 10. How to enrich the course using science history according to the prospective teachers

\begin{tabular}{llcc}
\hline Categories & \multicolumn{1}{c}{ Codes } & $\mathrm{f}$ & $\%$ \\
\hline $\begin{array}{l}\text { Teacher- } \\
\text { centered }\end{array}$ & $\begin{array}{l}\text { 1.The teacher may tell about lives, works, or inventions of scientists. } \\
\text { 2.The teacher may tell about the historical development process of mathematical } \\
\text { symbols, concepts, or formulas. }\end{array}$ & $\begin{array}{c}\text { 4 } \\
\text { sy.3 }\end{array}$ & 6.0 \\
\hline
\end{tabular}


Table 10. Continued

\begin{tabular}{|c|c|c|c|}
\hline Categories & Codes & $\mathrm{f}$ & $\%$ \\
\hline \multirow{6}{*}{$\begin{array}{l}\text { Teacher- } \\
\text { centered }\end{array}$} & 3.The teacher may tell stories or anecdotes from lives or about works of scientists. & 7 & 4.7 \\
\hline & $\begin{array}{l}\text { 4.The teacher may have students watch movies or videos related to lives of } \\
\text { scientists. }\end{array}$ & 7 & 4.7 \\
\hline & 5.The teacher may use quotes from scientists. & 3 & 2.0 \\
\hline & 6.The teacher may make stories out of lives of scientists. & 2 & 1.3 \\
\hline & 7.The teacher may mention historical problems. & 1 & 0.7 \\
\hline & 8.The teacher may tell about the historical development of mathematics. & 1 & 0.7 \\
\hline \multirow{11}{*}{$\begin{array}{l}\text { Material- } \\
\text { aided }\end{array}$} & 9.The teacher may have students write letters about lives of scientists. & 9 & 6.0 \\
\hline & 10.The teacher may have students create banners about lives of scientists. & 8 & 5.3 \\
\hline & 11.The teacher may have students make puzzles about lives of scientists. & 7 & 4.7 \\
\hline & 12.The teacher may have students prepare slide-shows about lives of scientists. & 2 & 1.3 \\
\hline & 13.The teacher may have students write screen plays about lives of scientists. & 2 & 1.3 \\
\hline & 14.The teacher may have create movies or videos about lives of scientists. & 1 & 0.7 \\
\hline & 15.The teacher may have students prepare worksheets about lives of scientists. & 1 & 0.7 \\
\hline & 16.The teacher may have students paint pictures about lives of scientists. & 1 & 0.7 \\
\hline & 17.The teacher may have students come up with slogans about lives of scientists. & 1 & 0.7 \\
\hline & 18.The teacher may have students create posters about lives of scientists. & 1 & 0.7 \\
\hline & 19.The teacher may have students create calenders about lives of scientists. & 1 & 0.7 \\
\hline \multirow{4}{*}{$\begin{array}{l}\text { Student- } \\
\text { centered }\end{array}$} & 20.The teacher may have students hold interviews about lives of scientists. & 4 & 2.7 \\
\hline & 21.The teacher may have students perform dramas about lives of scientists. & 3 & 2.0 \\
\hline & 22.The teacher may have students prepare plays about lives of scientists. & 2 & 1.3 \\
\hline & 23.The teacher may have students solve problems using theories of scientists. & 1 & 0.7 \\
\hline
\end{tabular}

As shown in Table 10, the suggestions of the prospective teachers about how to enrich the course using science history gathered under three different categories; "teacher-centered", "material-aided", and "student-centered". Also, the "The teacher may tell about lives, works, or inventions of scientists." code stood out in the teacher-centered category, whereas the "The teacher may have students write letters about lives of scientists." code stood out in the material-aided category, and the "The teacher may have students hold interviews about lives of scientists." code stood out in the student-centered category. Some quotes from the prospective teachers corresponding to codes 1, 9, and 20 in Table 10 can be found below:

“We can briefly tell about Pythagoras' life when explaining the Pythagorean Theorem in the mathematics class... (P33)"

"We can make use of science history by telling about lives and discoveries of scientists in mathematics classes... (P48)"

“...We can have students put themselves in shoes of a scientist, and write letters about the life of that scientist, or create interviews imagining how that scientist would answer questions... (P11)"

"We can write about lives of scientists in the form of a letter. We can interview scientists. (P20)"

\section{Discussion, Conclusion and Recommendations}

The findings obtained in this study aiming to reveal beliefs of prospective teachers about science and science history were discussed in light of the literature, and the following results were found:

It was found that the prospective teachers explained science mostly with the procedural understanding dimension. In this context, the prospective teachers defined science mostly as "the endeavor or process of understanding the nature" and "the endeavor or process of understanding the universe". Similarly, Ayvaci and Senel Coruhlu (2012) and Celik (2003) found that prospective teachers tended to define science with its procedural dimension. Another interesting finding was that the prospective teachers had contemporary views about science. Kenar (2008) relieved that prospective science teachers had contemporary views about the creative and imaginative nature of science. Cinar and Koksal (2013) found that prospective social studies teachers had traditional views about the definition of science. It was found that the prospective teachers explained science history mostly with the 
procedural understanding dimension as well. In this context, a significant portion of the prospective teachers defined science history as "an examination of science's historical development". We believe that the criteria given to the prospective teachers to use when researching scientists helped them better understand the procedural dimension of science and science history. Hacieminoglu et al. (2012) found that, after starting their careers as teachers, the most frequently addressed dimension by prospective teachers in their applications related to science history was the conceptual dimension, whereas the contextual dimension was mentioned the least. Hence, it is possible to improve understandings of prospective teachers about science and science history by emphasizing each of the conceptual, procedural, and contextual dimensions of science.

It was found that the prospective teachers attributed success in science mostly to cognitive factors. In this context, the prospective teachers frequently mentioned the necessity of intelligence, hard work, and keeping one's mouth shut. We believe that the reason behind the high frequency of these codes was the discussion held about Albert Einstein's famous quote, "If A is a success in life, then A equals x plus y plus z. Work is x; y is play; and $\mathrm{z}$ is keeping your mouth shut." in the first week of the courses about science history. Also, it was observed that the prospective teachers gave examples about factors leading to scientific success with a wide perspective. However, the frequency of these examples was low in spite of their high variety. If science history is addressed as a whole without ignoring any of its dimensions; conceptual, procedural, and contextual, the frequency of codes such as "enjoying science and hard work", "being curious", "thinking", or "researching and observing" may be improved. Thus, it may be possible to raise prospective teachers who think as contemporary scientists.

Although men and women have been working together in both social and scientific environments since the emergence of the humankind (Kocak, Taskin, \& Ozpinar, 2010), female scientists have not been able to demonstrate their talent on the desired level due to various reasons such as social and familial pressure (Yildiz \& Hacisalihoglu-Karadeniz, 2017). It was found that the prospective teachers attributed the low number of female scientists mostly to socio-cultural factors as well. The prospective teachers explained the reasons behind the low number of female scientists as "being denied a voice or an opportunity" and "social pressure". This and other finding in Table 7 indicate that the prospective teachers were informed about the effects of social and cultural factors on science, and explained the low number of female scientists mostly with the contextual dimension of science. Akerson, Abd-El-Khalick, and Lederman (2000) found that prospective teachers and prospective teachers had limited information about the relationship of science with society and culture. Aslan et al. (2009), on the other hand, found that prospective science teachers had sufficient knowledge about the influence of social and cultural factors on scientists and scientific research. Sarac (2012) and Yenice et al. (2015) revealed that prospective teachers had contemporary views about the effects of science on the society and the effects of society on science. Atalay (2013), on the other hand, found that prospective science teachers had limited knowledge about the effects of social and cultural factors on science. It should be remembered that scientists are not only affected by the contextual dimension of science, but also its conceptual and procedural dimensions as well. Hence, courses on science history should emphasize the conceptual dimension of science in order to help prospective teachers develop an understanding about what scientific thinking means and roles of scientific thinking. Also, the procedural dimension of science should not be ignored, too, in order to ensure prospective teachers understand how scientists think, how they carry out their research, how they analyze data, how they decide on results, and how they report these results.

The prospective teachers were found to have positive beliefs about the benefits of science history for the cognitive domain and the affective domain. The most commonly mentioned beliefs included learning about lives, works, inventions, or quotes of scientists and holding up to them as good examples. We believe that having prospective teachers make presentations about contributions of scientists from different periods in courses related to science history allowed them to learn lives, works, inventions, or famous quotes of scientists. Lacin Simsek (2011) revealed that reasons behind science and technology teachers' using science history in courses were mostly related to the cognitive domain. Cetiner (2016) found that activities related to science history improved prospective teachers' interest in the course, helped them understand concepts more easily, and ensured that they developed positive attitudes towards the course. Thus, it is evident that science history can be used to improve cognitive and affective traits of students. Explaining how old mechanical tools were developed and used, bringing examples of these tools to the classroom, creating simple models, or having students create such models may improve psychomotor skills of students.

The prospective teachers were found to believe that enriching courses with science history was mostly possible with teacher-centered approaches. In this context, the most common belief mentioned by the prospective teachers was "telling about lives, works, or inventions of scientists" as a way to benefit from science history in classes. This might be a result of the fact that the prospective teachers were asked to make presentations about lives, inventions, ideas, or scientific contributions of scientists throughout the study. Lacin Simsek (2011) found that science and technology teachers used science history in their classes by "telling life stories of scientists", "explaining the historical development processes of scientific subjects", "giving research or project assignments", "presenting examples from science history for certain subjects", and "telling stories from science history". This might be caused by books on science history and textbooks used in schools. Because Karabag (2015) found that history books used at the high school level usually 
included information about names and lives of scientists in relation to science history. The same examples related to science history are repeated over and over in popular books and textbooks, and science history is taught based on these examples (Metz, Klassen, McMillan, Clough, \& Olson, 2007). It may be natural for the prospective teachers to give examples from lives, works, and inventions of scientists. On the other hand, the number of examples about how to use science history in courses was observed to be higher. The reason behind the high number of examples was that some codes in Table 10 (such as writing letters, showing movies or videos, preparing posters and puzzles, telling stories or anecdotes) were used by the prospective teachers for their presentations. This might have caused an increase in their knowledge about how to use science history in courses. This may be accepted as a positive development. However, the frequency of examples was not so high. This might indicate low awareness or limited knowledge about how to use science history in courses. It was noted in the literature that teachers (Lacin Simsek, 2011) and prospective teachers (Hacieminoglu et al., 2012) had limited knowledge about science history. Therefore, teaching prospective teachers how to use science history in courses may positively influence and improve their views about science and science history.

Recommendations based on the results of this study are presented below:

- It was found that the prospective teachers explained science and science history mostly with the procedural dimension, and the other dimensions were pushed into the background. For this reason, conceptual and contextual dimensions of science should also be emphasized.

- The prospective teachers attributed the low number of female scientists to "being denied a voice or an opportunity" and "social pressure". Such socio-cultural factors cause significant problems, and push women to the background. In order to prevent this situation, it is recommended that "Gender Equality" is added to undergraduate programs as an optional subject. Mustafa Kemal Ataturk's quote, "Humankind is made up of two sexes, women and men. Is it possible for humankind to grow by the improvement of only one part while the other part is ignored? Is it possible that if half of a mass is tied to earth with chains that the other half can soar into skies!" should guide everyone in terms of gender equality (Demirgoz Bal, 2014). Also, another reason suggested by the prospective teachers for the low number of female scientists was the use of the term "science man" instead of "science person", which is a usage specific to the Turkish language. In this context, more caution needs to be exercised in relation to the use of the term "science person" instead of "science man" in classes, textbooks, and curricula.

- The prospective teachers were observed to lack the desired knowledge about the use of student-centered and material-aided approaches to use science history in courses. For this reason, prospective teachers can be provided with information about how to use student-centered and material-aided approaches in the "Science History" course and the "Nature of Science and Science History" course. Also, prospective teachers should be provided with opportunities to develop sample materials and activities related to the use of material-aided, teacher-centered, and student-centered approaches to teach science history, and also opportunities to implement these materials and activities in schools within the scope of the teaching applications course. Finally, revising the contents of the "Science History" course and the "Nature of Science and Science History" course and responsibilities of academics teaching these courses may be useful to this end.

In summary, this study was performed with 150 senior prospective teachers. Enriching the study with different study groups and research patterns may improve the validity of the findings. Also, the present study was conducted after the prospective teachers had taken the "Science History" course or the "Nature of Science and Science History" course. It may be useful to investigate their beliefs about science and science history before these courses.

\section{References}

Abd-El-Khalick, F.(2005). Developing deeper understandings of nature of science: The impact of a philosophy of science course on pre-service science teachers' views and instructional planning. International Journal of Science Education, 27(1), 15-42.

Akerson, V. L., Abd-El-Khalick, F., \& Lederman, N. G. (2000). Influence of a reflective explicit activity-based approach on elementary teachers' conceptions of nature of science. Journal of Research in Science Teaching, 37(4), 295-317.

Appelget, J., Matthews, C. E., Hildreth, D. F., \& Daniel, M. L. (2002). Teaching the history of science to students with learning disabilities. Intervention in School and Clinic, 37(5), 298-303.

Aslan, O., Yalcin, N., \& Tasar, M. F. (2009). The views of the teachers of the science and technology on the nature of science. Ahi Evran University Journal of Kirsehir Education Faculty, 10(3), 1-8.

Atalay, O. E. (2013). Exploring scientists' and secondary science and technology teachers' views about nature of science. Unpublished master's thesis, Trakya University, Edirne.

Ayvaci, H. S., \& Senel, C. T. (2012). Investigating the views of the pre-service science teachers about the science and science. Dicle University Journal of Ziya Gokalp Faculty of Education, 19, 29-37. 
Bayrakdar, M. (2009). The history of science and technology in Islam (6th Edition). Ankara: Turkish Religious Foundations Publishing.

Bilen, K. (2015). What is science? What is not? In N. Yenice (Ed.), The nature, development, and teaching of science (pp. 1-44). Ankara: Ani Publishing.

Bozdogan, B., Sengul, U., \& Bozdogan, A. E. (2013). The examination of prospective science teachers' level of knowledge about scientists: Giresun faculty of education sample. The Black Sea Journal of Social Sciences, 5(9).

Celik, S. (2003). The perspective teachers' views of the nature of science and influence of "science, technology and society" course on these views. Unpublished master's thesis, Ataturk University, Erzurum.

Cetiner, A. Y. (2016). Student opinions about the physics activities including the first experiments carried out in the history of science -Archimedes-The crown of the king sample- Unpublished master's thesis, Gazi University, Ankara.

Cinar, M., \& Koksal, N. (2013). Social studies pre-service teachers' views on science and the nature of science. Mersin University Journal of the Faculty of Education, 9(2), 43-57.

Council of Higher Education [CoHE]. (2007). Faculty of education and teacher training undergraduate programs, Turkish council of higher education. Ankara.

Demirgoz, B. M. (2014). General overview of gender inequalities. Journal of Women's Health Nursing, 1(1), 15-28.

Dogan, M. (2016). History of science and technology (3rd Ed.). Ankara: Ani Publishing.

Ekiz, E. (2009). Scientific research methods (Revised 2nd Ed.). Ankara: Ani Publishing.

Fazlioglu, I. (2004). A bridge with two vague edges: "History" with "science" or "history of science". Turkish Studies Review, 2(4), 9-27.

Hacieminoglu, E., Ertepinar, H., \& Yilmaz-Tuzun, O. (2012). Pre-service science teachers' perceptions and practices related to history of science instructions. International Journal on New Trends in Education and Their Implications, 3(3), 53-59.

Justi, R., \& Gilbert, J. K. (1999). History and philosophy of science through models: The case of chemical kinetics. Science and Education, 8, 287-307.

Karabag, S. G. (2015). History of science and medicine in Turkish history secondary school textbooks. International Journal of Environmental \& Science Education, 10(2), 287-300.

Kenar, Z. (2008). Prospective science teachers' views of the nature of science. Unpublished master's thesis, Balikesir University, Balikesir.

Kocak, Z. F., Taskin, F., \& Ozpinar, F. (2010). The place and significance of women in the world of mathematics. In F. Coban Doskaya (Chief Ed.), Women on the verge of the 21st century: Change and empowerment (Volume III) (pp. 69-75). Izmir: Dokuz Eylul University Faculty of Arts and Sciences Publications.

Kocyigit, A., \& Pektas, M. (2017). An investigation of middle school science textbooks' inclusion of history of science. Cumhuriyet International Journal of Education, 6(1), 185-199.

Lacin, S. C. (2009). How much and how science and technology curriculums and textbooks benefits from history of science? Elementary Education Online, 8(1), 129-145.

Lacin, S. C. (2011). Science and technology teachers' situation of integrating history of science into their lessons. International Online Journal of Educational Sciences, 3(2), 707-742.

Lederman, N. G., Abd-El-Khalick, F., Bell, R. L., \& Schwartz, R. S. (2002). Views of nature of science questionnaire: Toward valid and meaningful assessment of learners' conceptions of nature of science. Journal of Research in Science Teaching, 39(6), 497-521.

McComas, W. F. (2008). Seeking historical examples to illustrate key aspects of the nature of science. Science \& Education, 17, 249-263.

McMillan, J. H., \& Schumacher, S. (2006). Research in education: Evidence-based inquiry (6th Ed.). Boston: Pearson.

Metin, D. (2009). The effectiveness of guided-inquiry and explicit nature of science activities applied at a summer science camp on sixth and seventh grade children's views of the nature of science. Unpublished doctoral thesis, Abant Izzet Baysal University, Bolu.

Metz, D., Klassen, S., McMillan, M., Clough, M., \& Olson, J. (2007). Building a foundation for the use of historical narratives. Science \& Education, 16, 313-334. 
Miles, M. B., \& Huberman, A. M. (1994). Qualitative data analysis: An expanded sourcebook (2nd Ed.). Thousand Oaks, California: SAGE Publications.

Monk, M., \& Osborne, J. (1997). Placing the history and philosophy of science on the curriculum: A model for the development of pedagogy. Science Education, 81, 405-424.

Ortas, I. (2005a). Why did we publish a special issue about science history? University and Society, 5(1), 1.

Ortas, I. (2005b, September 10). Why should we teach science history? Retrieved from http://www.kenthaber.com/Arsiv/Haberler/2005/Eylül/10/Haber_84411.aspx

Palmquist, B. C., \& Finley, F. N. (1997). Pre-service teachers' views of the nature of science during a post baccalaureate science teaching program. Journal of Research in Science Teaching, 34(6), 595-615.

Posnanski, T. J. (2010). Developing understanding of the nature of science within a professional development program for in-service elementary teachers: Project nature of elementary science teaching. Journal of Research in Science Teaching, 47(10), 589-621.

Rutherford, F. J. (2001). Fostering the history of science in American science education. Science \& Education, 10, 569-580.

Sarac, E. (2012). The views of the elementary teachers and pre-service elementary teachers about the nature of science. Unpublished master's thesis, Akdeniz University, Antalya.

Strauss, A., \& Corbin, J. (1998). Basics of qualitative research: Techniques and procedures for developing grounded theory (2nd Ed.).Thousand Oaks, CA: Sage Publications.

Tekeli, S., Kahya, E., Dosay, M., Demir, R., Topdemir, H. G., \& Unat, Y. (1997). History of science (1st Ed.). Ankara: Doruk Publications.

Tekeli, S., Kahya, E., Dosay, M., Demir, R., Topdemir, H. G., Unat, Y., \& Aydin, A. K. (2007). Introduction to the history of science (4th Ed.). Ankara: Nobel Academy Publishing.

Topdemir, H. G., \& Unat, Y. (2008). History of science (3rd Ed.). Ankara: PEGEM Academy Publishing.

Turkish Language Association Dictionary [TLAD]. (2011). Turkish dictionary. Ankara: Turkish Language Association Publications.

Wang, H. A., \& Marsh, D. D. (2002). Science instruction with a humanistic twist: Teachers' perception and practice in using the history of science in their classrooms. Science and Education, 11, 169-189.

Yenice, N. (2015). Opinions about the nature of science. In N. Yenice (Ed.), The nature, development, and teaching of science (pp. 339-387). Ankara: Ani Publishing.

Yenice, N., Ozden, B., \& Balci, C. (2015). Examination of views about nature of science of pre-service science and elementary school teachers'. Erzincan University Journal of Education Faculty, 17(1), 237-281.

Yildirim, A., \& Simsek, H. (2011). Qualitative research techniques in social sciences (8th Ed.). Ankara: Seckin Publications.

Yildirim, C. (2003). History of science (8th Ed.). Istanbul: Remzi Bookstore.

Yildirim, C. (2007). Philosophy of science (11th Ed.). Istanbul: Remzi Bookstore.

Yildiz, C., \& Gokcek, T. (2013, November 22-24). Using life stories in mathematics teaching. International Symposium on Changes and New Trends in Education, Necmettin Erbakan University, Konya.

Yildiz, C., \& Hacisalihoglu-Karadeniz, M. (2017). A study on developing activities for familiarizing the women mathematicians who become prominent in the republic period and after. The Black Sea Journal of Social Sciences, 9(9), 297-320.

Yorukogullari, E., \& Ihsanoglu, E. (Ed.) (2013). History of science and technology. Eskisehir: Anadolu University Publications.

\section{Copyrights}

Copyright for this article is retained by the author(s), with first publication rights granted to the journal.

This is an open-access article distributed under the terms and conditions of the Creative Commons Attribution license which permits unrestricted use, distribution, and reproduction in any medium, provided the original work is properly cited. 